\title{
ТЕОРІЇ ВИЗНАЧЕННЯ Й ОЦІНКИ ПОТРЕБ І ПРОБЛЕМ КОРИСТУВАЧІВ ПОСЛУГ ВІЙСЬКОВО-СОЦІАЛЬНОЇ РОБОТИ ЯК ДІєВОЇ СЛУЖБИ ДОПОМОГИ ЛЮДЯМ
}

\author{
Трубавіна I. М.
}

доктор педагогічних наук, професор, професор кафедри соціальногуманітарних дисциплін Національної академії Національної гвардії України, м. Харків, Україна

Стаття присвячена огляду теорій оиінки потреб і проблем військовослужбовиів і членів їхніх сімей у сучасній Україні як користувачів послуг військово-соиіальної роботи. Військово-соиіальна робота розглядається як дієва служба допомоги людям у період військових конфліктів і пандемії, гуманітарної кризи. У статті виділені типи проблем сучасних військовослужбовців і членів їхніх сімей.

Ключові слова: військово-сочіальна робота, військовослужбовеиь, члени сімей військовослужбовців, теорії оцінки проблем і потреб, класифікація, проблема військовослужбовиів.

The article is devoted to the review of theories of assessment of needs and problems of servicemen and members of their families in modern Ukraine as users of military and social work services. Military and social work is seen as an effective service to help people during military conflicts and pandemics, humanitarian crises. The article highlights the types of problems of modern servicemen and members of their families.

Key words: military and social work, serviceman, members of families of servicemen, theories of assessment of problems and needs, classification, problem of servicemen.

Військово-соціальна робота є актуальним напрямом морального і духовного виховання сучасних військовослужбовців, гарантією підтримки і допомоги їм і членам їхніх сімей, дієвою службою допомоги людям, що є важливим під час військового конфлікту на Сході України, пандемії, гуманітарної кризи в сучасному суспільстві. Військово-соціальна робота як відомча система допомоги військовослужбовцям завжди посідала більш вагоме місце в період війни та після них. Не виключенням $\epsilon$ й сучасні проблеми військовослужбовців, які масово беруть участь в АТО/ООС. Проте якісні та адресні соціальні послуги можливі лише на основі оцінки потреб і проблем користувачів послуг. Розкриємо теорії, які дозволяють це зробити.

Користувачі послуг військово-соціальної роботи - військовослужбовці і члени їхніх сімей. $€$ теорії оцінки потреб дітей [1], теорії 
соціальної роботи з військовослужбовцями [2], опис проблем військовослужбовців сектору безпеки і оборони України [3], але відсутні сучасні теорії оцінки потреб і проблем військовослужбовців. Між тим їхні потреби і проблеми є основою для визначення обсягу, терміну допомоги, що реалізує клієнтоцентричний, людиноцентричний підходи до військово-соціальної роботи. Зазначимо, що в основі надання допомоги може бути проблемно-орієнтований підхід або орієнтований на завдання підхід, за якими в центрі військово-соціальної роботи $\epsilon$ першочергові, ключові проблеми людей, невирішення яких призводить до погіршення ситуації. Для розв'язання проблем треба вміти вивчати проблеми і потреби людей, володіти тенденціями щодо них, способів їх вирішення, попередження.

Виділяють схожі теорії життєстійкості, життєтворчості, порушення особистісного потенціалу особистості, життєтворчого потенціалу особистості, за якими, згідно Л. Сохань, «життєтворчий потенціал та життєтворчий талант (як його складова) реалізуються в побудові особистістю свого індивідуального життя» [4, с.137]. Неможливість військовослужбовців будувати свої життя і життя своєї сім’ї в силу різних факторів є основою для соціальної роботи 3 ними.

Існує також теорія відновлення. Згідно до неї, люди захищені не лише природою розвитку, але й діями оточення і своїми власними діями, розвитком своїх сильних сторін, можливостями досягнення успіху й успішним досвідом (А. Masten, J. Coatsworth та ін.) [5]. Йдеться про здатність особистості до відновлення внутрішніх ресурсів після кризи, стресу самомобілізацією, підтримкою найближчого оточення та середовища, що важливо для реабілітації особистості, її сім’ї після кризи, тривалого дистанціювання в силу участі члена сім'ї у бойових діях, лікування, після поранення, інвалідності тощо.

Серед характеристик здатності до відновлення на індивідуальному рівні вчені вирізняють: безумовне прийняття (ставлення до себе, що базується на відчутті власної гідності, усвідомленні особистісної цінності; любов у повному сенсі цього слова; володіння якостями оптимізму, сприйняття себе як унікальної неповторної особистості); адекватна самооцінка; віра у себе та здатність долати труднощі (упевненість у власних можливостях долати складні життєві обставини; уміння вирішувати життєві проблеми); ініціатива (можливість і прагнення діяти); оптимізм (життєрадісне світосприйняття, віра у краще майбутнє, успіх); довіра (упевненість у добросовісності, щирості інших і побудоване на цьому ставлення до інших); прив’язаність (просторово-часове почуття 
близькості, що створює міцний емоційний зв'язок, відчуття захищеності); опанування соціальними ролями (володіння соціальними ролями як ресурсу позитивної самоідентифікації та власної гідності); участь у прийнятті рішень та житті суспільства (можливість ухвалювати рішення; здатність брати відповідальність за власні вчинки; розвиток саморегуляції, у тому числі контролю власних емоцій та поведінки; бажання та вміння планувати); здатність раціонального осмислення подій (уміння аналізувати те, що сталося; відсутність остраху робити помилки, готовність учитися на власних помилках, розглянувши всі їх причини та наслідки; навички розрізнювати небезпеку); ідентичність (відчуття приналежності до певної групи: соціальної, культурної, релігійної, мовної тощо; уподібнення себе ідеалу, герою, еталону тощо); відкритість до нових стосунків та комунікабельність (бажання та вміння налагоджувати нові стосунки, конструктивно спілкуватися); гумор (беззлісно-висміювальне ставлення до чогось; допомагає уникати негативних емоцій, встановлювати та підтримувати міжособистісні зв'язки) [6].

Близька до неї теорія резилієнсу — опора на сильні сторони людини при наданні допомоги їй і теорія активізації щодо зусиль самої людини у вирішенні їі проблем [7].

Отже, військово-соціальна робота передбачає вивчення проблем для активізації потенціалу людини у їх вирішенні, а не розв'язанні проблем за неї. Це перегукується 3 теорією участі молоді у вирішенні своїх проблем ЮНІСЕФ. Соціально-педагогічні теорії соціальної роботи наголошують на тому, що діагностика в роботі з військовослужбовцями та членами їхніх сімей полягає у вивченні та аналізі фахівцями особливостей особистості і сім’ї, факторів і стресорів, які впливають на їхній розвиток і функціонування, викликають кризу, реалізацію прав, задоволення потреб та інтересів, виконання функцій та обов'язків. На цій основі здійснюється втручання або навчання іншій моделі поведінки.

Діагностика проблем вимагає знання наукових методів їх дослідження, а також типових проблем військовослужбовців і членів їхніх сімей. Пропонуємо класифікацію проблем користувачів військово-соціальної роботи, як-от: 1. Проблеми, які пов'язані з особистістю та ії статусом і стосунками в колективі: 1.1. Проблеми особистісні; 1.2. Проблеми сімейні; 1.3. Проблеми в колективі; 1.4. Міжособові проблеми; 1.5. Проблеми, які пов' язані з комункацією по службі. 2. Проблеми, які пов’язані зі статусом військовослужбовця чи члена його сім’ї в суспільстві: 2.1. Соціальні проблеми учасників АТО/ООС та членів їхніх сімей; 2.2. Проблеми іміджу і поваги в суспільстві; 2.3. Проблеми реалізації 
державних соціальних гарантій військовослужбовцям і членам їхніх сімей. 3. Проблеми, які пов'язані з пандемією та іншими надзвичайними ситуаціями: 3.1. Ті, які потребують короткочасного негайного реагування і втручання (лікування, відновлення тощо); 3.2. Тi, які вимагають постійної допомоги (стійка втрата працездатності тощо). Така типологія проблем користувачів військово-соціальної роботи дозволяє визначити обсяг, термін, вид допомоги через військово-соціальну роботу.

На основі викладеного можна дійти висновку про існування різних проблем і потреб військовослужбовців України та членів їхніх сімей у сучасному світі, різні підходи і теоретичні основи до їх діагностики і виявлення. Не існує ідеального підходу, але є набір підходів, що дозволяє обрати різні відповідні методи діагностики проблем і потреб користувачів військово-соціальної роботи.

\section{Список використаних джерел:}

1. Звєрєва І. Д., Кияниця 3. П., Кузьмінський В. О., Петрочко Ж. В. Оцінка потреб дитини та їі сім'ї: від теорії до практики : навч. посіб.: У 2-х част. К. : «Кожній дитині», 2010. Ч. І. 224 с.

2. Трубавіна I. М., Каліна К. С, Байдала В. В. До питання про теоретичні основи соціальної роботи з військовослужбовцями (на основі світових і вітчизняних теорій). Вісник ЛНУ імені Тараса Шевченка. Педагогічні науки. 2020. № 7 (338). С. 211-224.

3. Соціальні аспекти військово-професійної діяльності сектора безпеки і оборони: виклики сьогодення» : I Міжнар. наук.-практ. конф. (20.05.2021) : зб. тез доповідей. Х. : НА НГУ, 2021. 336 с.

4. Сохань Л. В. Искусство жизнетворчества. Предназначение. Жизнетворчество. Судьба: Социологические очерки, социально-психологические эссе, интервью, глоссарий. Київ : Издательский дом Дмитрия Бураго. 2010.

5. Masten, A. S., Coatsworth, J. D., Neemann, J., Gest, S. D., Tellegen, A. and Garmezy, N. The Structure and Coherence of Competence from Childhood through Adolescence. Child Development 66. 1995. 1635-59.

6. Gilligan, R. (1997). Beyond Permanence. The Importance of Resilience in Child Placement Practice and Planning. Adoption and Fostering 21(1). P. 12-20.

7. Iryna Trubavina, Olena Karaman, Dimitrina Kamenova, Viktoriia Stepanenko and Yaroslava Yurkiv. The response strategy of social work with displaced families and the receiving community (within the context of sustainable development). Second International Conference on Sustainable Futures: Environmental, Technological, Social and Economic Matters (ICSF 2021) : E3S Web Conf. 2021. Vol. 280. 04010 (2021). https://doi.org/10.1051/e3sconf/202128004010 